\title{
IMPACT OF TAX POLICY ON THE BUSINESS ECONOMY
}

\section{Miriam Buliková*, Peter Bielik, Stefaniia Belinska}

\author{
Slovak University of Agriculture in Nitra, Nitra, Slovakia
}

\begin{abstract}
Taxation and tax policy are relatively much-discussed topics within every society, and this has been so in the past, it is today, and it will be in the future. This is mainly due to the fact that no person or company is too fond of having to pay a certain part from their funds to the state in the form of taxes. Each state chooses its own tax policy and its own tax system so that the specified tax policy does not impede economy and economic development, but on the contrary, supports the business and economic growth. After the accession of the Slovak Republic to the European Union, Slovakia had to accept a certain state of tax regulations and rules that was valid in the European Union. This was mainly in order to use the common European market. The Slovak Republic has created its tax system in accordance with the rules of the European Union and has been trying to find a compromise between the amount of taxes necessary for the fulfilment of the state budget and the amount of taxes that would be most acceptable for the business sector and for people. Within the tax system, the Slovak Republic divides taxes into direct and indirect taxes, direct taxes imposed on labour, income and property, and taxes on consumption by indirect taxes. Recently, the prevailing opinion is that taxation should gradually shift from direct taxes to indirect taxes, to motivate people and businesses to achieve the best possible results, and subsequently raise the necessary funds based on the increased consumption. Recently, both in Slovakia and in the European Union, new excise taxes have been increasingly introduced. Traditional excise taxes such as taxes on mineral oils and fuels, tobacco and alcoholic beverages are complemented by energy, environmental, and electronic taxes. Slovakia and the European Union want to reduce the burden on the environment through these taxes on the one hand, and on the other hand, they must respond to the new challenges of globalization, information, and communication.
\end{abstract}

Keywords: business economics, tax, tax burden, tax implications, tax policy

\section{Introduction}

Tax policy not only affects the economic and business environment, but also very much affects the standard of living of the population within a state (Medved' et al., 2009). Through the tax system, almost $90 \%$ of public budget revenues are often generated (Lénártová et al., 2012). Some countries tend to consolidate their public finances by disproportionately raising taxes, which worsens the business environment and at the same time increases the risk of tax evasion. In this case, taxpayers often seek measures to reduce taxes to the minimum and maximize their profits. It should be noted that the relationship between the tax revenue that a country receives from the public budgets and the level of taxation within that country is not linear. It can be stated that as the tax rate increases, revenues from the tax system are constantly decreasing. This is also indicated by the Laffer curve of the American economist Arthur Laffer (Lisý et al., 2011).

To determine the tax burden, it is necessary to know all taxes, whether direct or indirect, as well as all mandatory payments that are levied on taxable persons within a given state. Through the tax burden, the state obtains funds, which it then spends to ensure the set goals within the framework of individual state policies (Beličková, 2004). The amount of the tax burden itself in individual countries can be determined based on various measurement methods, and these methods are mainly based on microeconomic and macroeconomic contexts (Schultzová, 2007). The amount of the tax burden depends to a large extent on: the amount of the tax rate of certain direct and indirect taxes; the extent of tax incentives, tax exemptions, tax credits and tax reliefs. For tax subjects - natural persons, this also depends on the social status of a person and on the number of persons that the tax subject maintains (Šrenkel and Smorada, 2017). A typical feature of direct taxes is that a taxable person bears the tax burden, and when the tax is levied, it is always known which taxable person must pay the given tax. Individual taxes, their calculation and all conditions related to the calculation and payment of the tax itself are regulated by legislation (Babčák, 2015). Indirect taxes can be understood as the oldest forms of taxation, which, on the one hand, have the task of providing revenues to the state budgets, at the same time taxing consumption. Indirect taxes still maintain a relatively privileged position in various tax systems (Schultzová et al., 2015). Tax optimization tools can also include depreciation methods. Depreciation plays an important role in assessing the efficiency of business and at the same time affects the economy of a company and especially relatively closely in relation to corporate taxes. Depreciation can have a significant impact on the overall management of a company and therefore on the amount of tax paid (Bielik et al., 2018). If the controlling system is configured correctly, its coordination function fully supports effective communication in all organizational subsystems of the company and, thus, management can make the right decisions in all areas, including tax planning (Gurčík, 2004).

\section{Material and methods}

The aim of the work is to find an effective variant of corporate income taxation, while the given variant of taxation should have a positive impact on business activity and competitiveness of companies in the selected sector of the economy and at the same time such taxation is still beneficial for the state.

The quantitative survey took the form of a questionnaire survey on a selected sample of respondents, while the given sample was larger than the minimum set sample within the survey objects (more than 400 small and medium-sized enterprises).

Based on the appropriate methodology for determining the sample size, it is possible to determine the minimum sample according to formula:

$$
n \geq \frac{\left(z^{2} \times p \times q\right)}{\Delta^{2}}
$$

where:

the variable $n$ represents the minimum sample size. The variables $p$ and $q$ represent the percentage of objects that can be inclined to one or the other 
variant. The selection of individual subjects within the sample will be purely random, and therefore the individual variables $p$ and $q$ were determined by dividing the whole sample in halves (50\% represents the variable $p, 50 \%$ represents the variable $q$ ).

The variable $z$ itself determines the coefficient of reliability of the given statement. If the reliability coefficient of a claim is set to 1 , the probability of the claim is guaranteed to be at least $68.3 \%$. If the reliability coefficient of a claim is set to 2, a probability of at least $95.4 \%$ of the given claim is guaranteed within the research.

The value $\Delta$ is the maximum permissible error.

The number of objects to be examined will be based on the following assumptions:

$\square$ the likelihood of a claim should be at the level of $z=2$, which means $95.4 \%$ reliability of the claim;

$\square$ the value of the maximum permissible error may be at the level of no more than 0.05 , which represents $5 \%$.

Based on the above assumptions and values, the minimum number of samples to be included in the sample was calculated, with at least 400 small and medium-sized enterprises operating in the selected sector of economy, which are agricultural holdings.

The specified minimum number of enterprises was selected at random from 6,540 enterprises, which are classified according to SK NACE 2 among agricultural entities. The sample consisted of randomly selected enterprises, with the basic condition being that the enterprises in the agricultural and forestry sector regularly publish their financial statements in the Register of Financial Statements.

Individual questions were scored statistically by a percentage evaluation based on the number of responses to the individual options offered. At the same time, some questions were assessed on a rating scale, when individual possible answers were assigned points from 1 to 5 , and then the number of answers to individual options was multiplied by the number of points assigned to the given answer. Subsequently, the arithmetic mean was calculated and based on the resulting value, and the answer to the question was estimated.

\section{Results and discussion}

The quantitative survey was carried out in the form of a questionnaire. The prepared questionnaire was sent to individual business entities operating in the selected agricultural sector. The questionnaire itself was processed via a form on the internet portal docs.google.com. The largest group (77.9\%) consisted of respondents who stated that their company has the form of a legal entity, regardless of whether it was a limited liability company, a commodity company, a joint-stock company, or another form of legal entity. Natural persons (12.5\%) and cooperatives (9.6\%) had approximately the same representation in the conducted questionnaire survey (Figure 1).

Individual respondents who took part in the survey answered research questions related to the problems investigated and solved in the paper.

Your annual turnover, resp. your company. The answers to this question obtained in the questionnaire survey are evaluated in the following Figure 2.

The largest group (50.6\%) consisted of business entities whose annual turnover did not exceed 100 thousand euros. The second largest group $(36.7 \%)$ consisted of business entities, whose annual turnover ranged from 100 to 500 thousand euros. A relatively small group (12.7\%) consisted of business entities with an annual turnover of more than 500,000 EUR.

Number of employees. The answers to this question obtained in the questionnaire survey are evaluated in the following Figure 3.

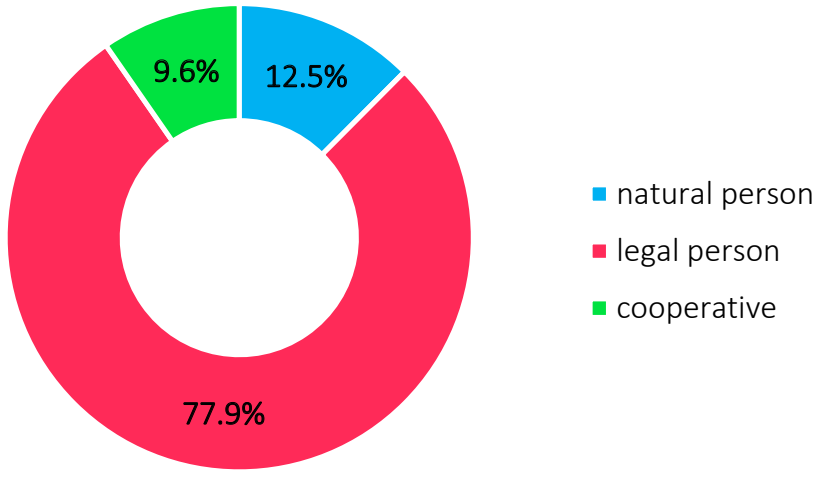

Figure 1 Form of business ownership Source: authors' own calculations

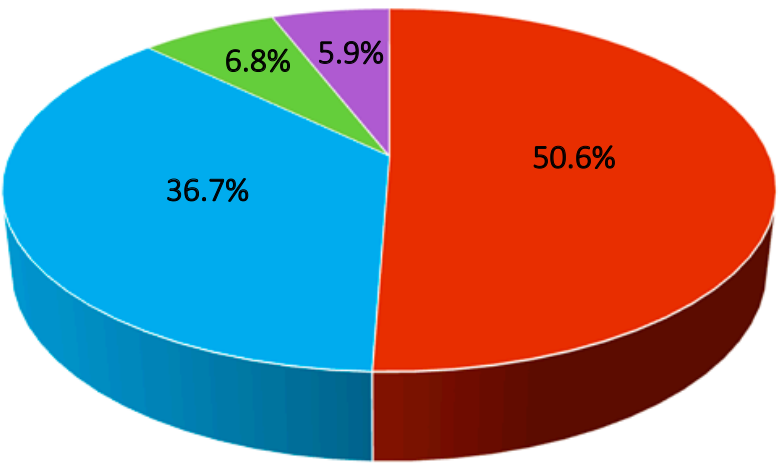

$$
\begin{aligned}
& -<100,000 \text { EUR } \\
& -100,001-500,000 \text { EUR } \\
& \text { - 500,001-1,000,000 EUR }=>1,000,001 \text { EUR }
\end{aligned}
$$

Figure 2 Annual turnover of business entities Source: authors' own calculations

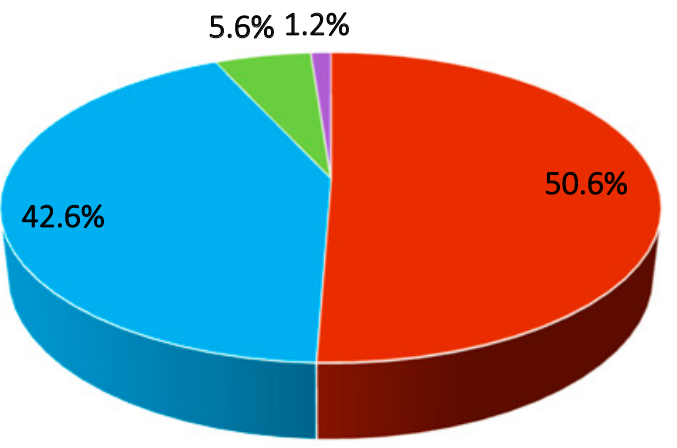

$$
\begin{array}{ll}
\text { - }<\text { employees } & \text { - 6-20 employees } \\
\text { - 21-100 employees } & >101 \text { employees }
\end{array}
$$

Figure 3 Number of employees of business entities Source: author' own calculations 


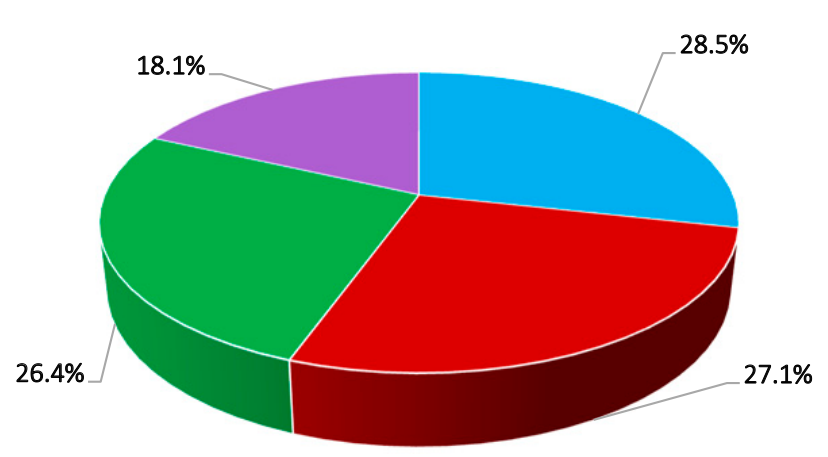

- I pay income tax every year

- I regularly pay income tax

- in some places I receive tax liabilities related to income tax

- my business is regularly unprofitable, so I do not pay income tax

Figure 4 Classification of companies in terms of payment of income taxes Source: authors' own calculations

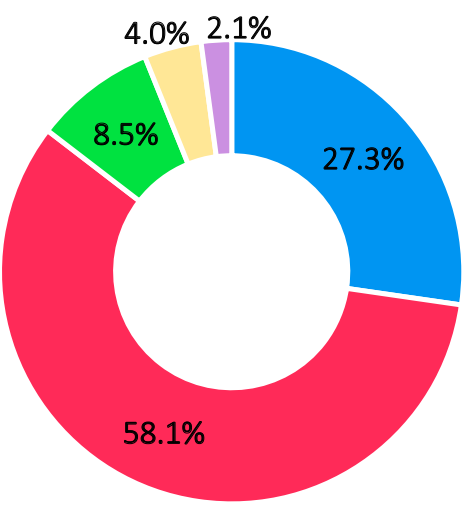

- very high

- high

- medium

- low

- very low

Figure 5 Assessment of the current tax burden Source: authors' own calculations

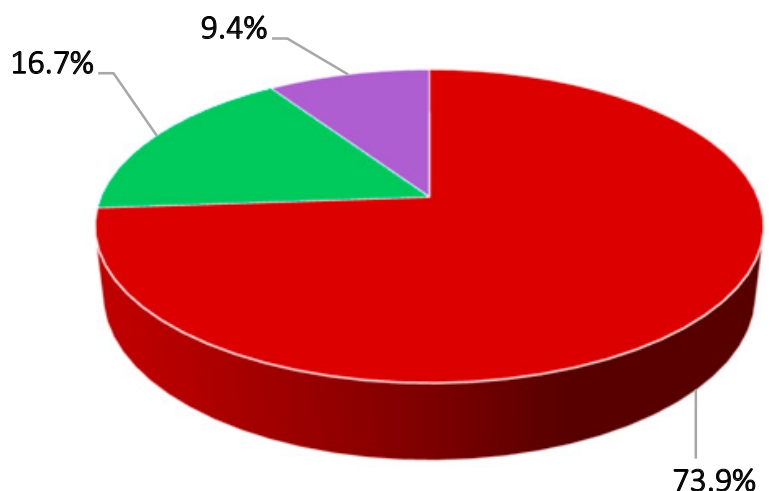

- flat tax - progressive tax - regressive tax

Figure 6 Optimal tax burden Source: authors' own calculations
As it turned out from the conducted questionnaire survey, the vast majority (93.2\%) of business entities have a maximum of 20 employees, while more than half of business entities (50.6\%) employ 5 or less employees.

In which group you can be placed, or your company? The answers to this question obtained in the questionnaire survey are evaluated in the following Figure 4.

The largest group (28.5\%) consisted of respondents who stated that they, or their business entity, pay income tax annually. Altogether $55.6 \%$ of business entities in the agricultural sector who participated in the questionnaire survey pay income tax every year or regularly. $44.4 \%$ of business entities do not regularly pay income tax, while $18.1 \%$ of business entities declare that their business is regularly unprofitable and for this reason do not pay income tax, which is in strict conflict with the basic principle of business, which is enforcement within a competitive market and making a profit in the course of their business activities. The questionnaire survey did not examine the question of the amount of tax paid by individual business entities that participated in the questionnaire survey, therefore it is impossible to determine the amount of income tax paid by those organisations that stated that this tax is paid on a regular or annual basis.

How do you assess the current tax burden? The answers to this question obtained in the questionnaire survey are evaluated in the following Figure 5.

The largest group (58.1\%) consisted of business entities, which stated that the current tax burden is rather high. $85.4 \%$ of business entities agreed that the current tax burden is to some extent high.

What is the optimal tax burden in your opinion? The answers to this question obtained in the questionnaire survey are evaluated in the following Figure 6.

The largest group (73.9\%) of respondents consisted of tax subjects, who stated that from their point of view, the optimal tax burden is a flat tax. The smallest group (9.4\%) consisted of respondents who could imagine a degressive system of taxation of income tax as the optimal tax burden.

What do you think is the optimal income tax rate? The answers to this question obtained in the questionnaire survey are evaluated in the following Figure 7.

The largest group (66.1\%) of respondents who participated in the questionnaire survey consisted of tax subjects who stated that, from their point of view, the optimal income tax burden is at the level of $11 \%$ to $15 \%$. On the contrary, the smallest group (3.3\%) were the respondents who participated in the questionnaire survey and who stated that the optimal

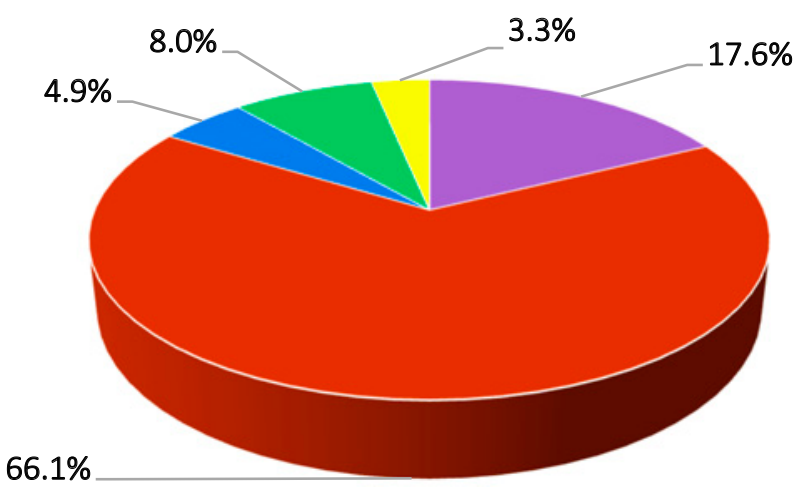

$=<10 \%=11-15 \% \quad-16-20 \% \quad-21-25 \% \quad->25 \%$

Figure 7 Optimal income tax rate Source: authors' own calculations 


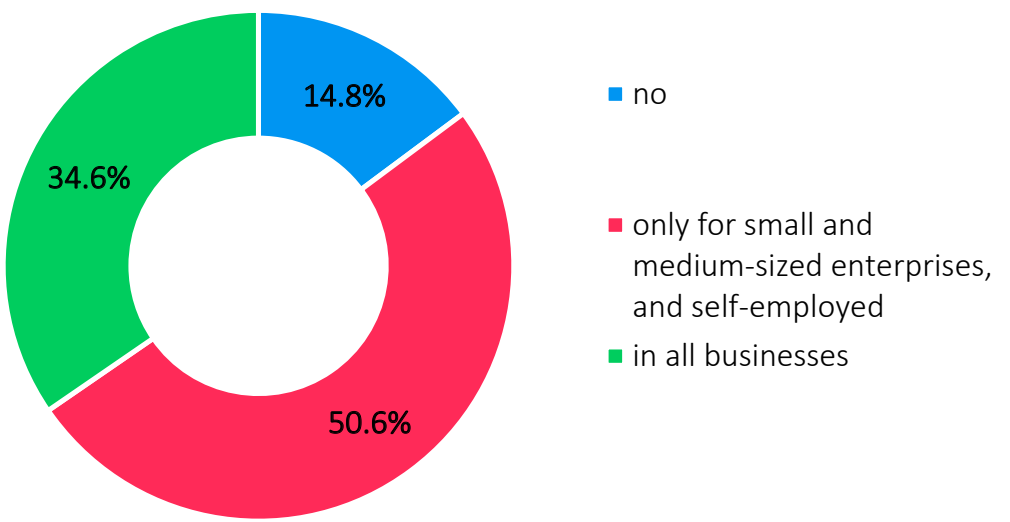

Figure 8 Promoting employment through tax policy Source: authors' own calculations

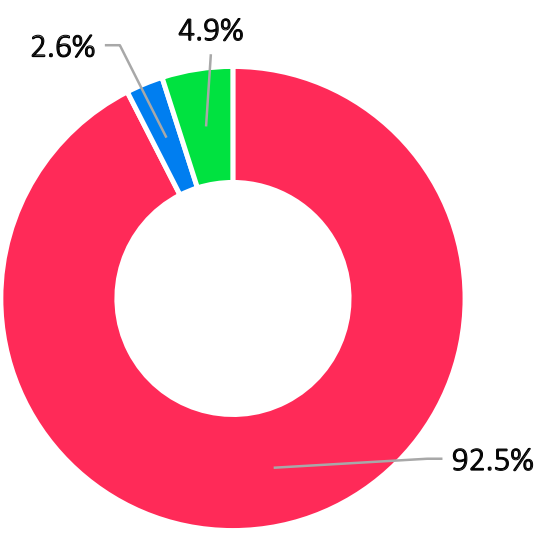

- yes, I receive a subsidy every year

- yes, but not every year

no, I do not receive the subsidy

Figure 9 Receiving a subsidy from the state or the EU Source: authors' own calculations

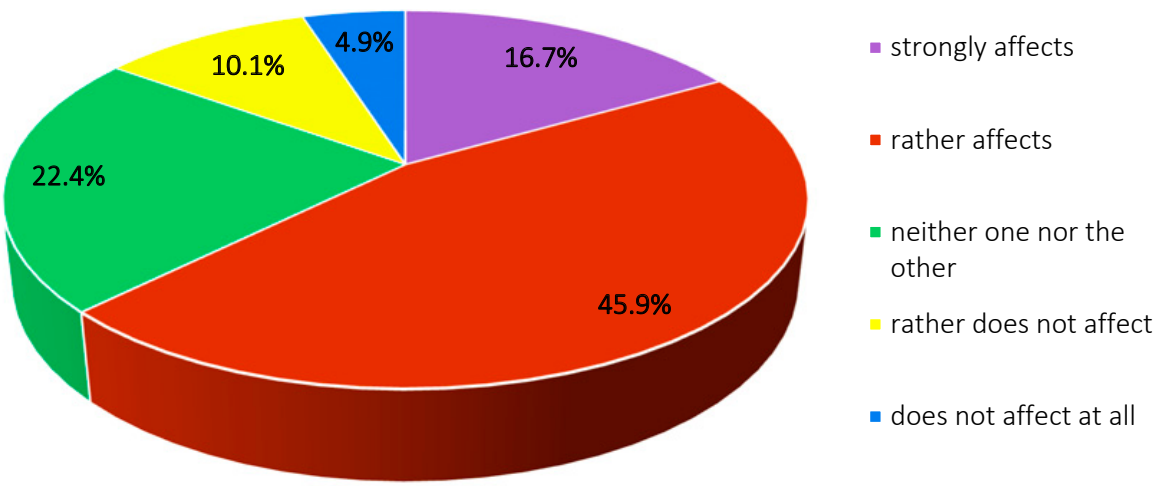

Figure 10 Influencing the subsidy of the economy of business entities Source: authors' own calculations income tax burden should be more than $25 \%$. The given tax burden for income tax would be higher than in the current period.

Should tax policy support employment? The answers to this question obtained in the questionnaire survey are evaluated in the following Figure 8.

A total of $85.2 \%$ of respondents from several business entities who took part in the questionnaire survey stated that the state could support employment through tax policy. 50.6\% of respondents stated that such employment support through tax policy should be available only for small and medium-sized enterprises, or for natural persons - entrepreneurs (selfemployed persons).

Do you receive state or EU-based subsidies due to your business? The answers to this question obtained in the questionnaire survey are evaluated in the following Figure 9.

In general, up to $92.5 \%$ of respondents from a number of business entities in the agricultural sector who participated in the questionnaire survey stated that they receive a subsidy either directly from the state or from the European Union, while the subsidy is directly related to their business activities.

Does the mentioned subsidy affect your economy or your company and consequently the amount of income tax paid? The answers to this question obtained in the questionnaire survey are evaluated in the following Figure 10.

The majority of respondents (62.6\%) from the number of business entities who participated in the questionnaire survey stated that the allocated subsidies affect the economy of business entities and subsequently also affect the amount of income tax paid by business entities in the tax period in favour of the public budget. The total of $15.0 \%$ of respondents stated that the drawn subsidy does not affect the economy of business entities at all or only in a certain way and subsequently also affects the amount of income tax paid by the business entity within the given tax period in favour of the public budget. The total of $22.4 \%$ of respondents who participated in the questionnaire survey of business entities in the agricultural sector could not lean to either side.

Based on statistical recalculations, it can be stated that the resulting coefficient of influencing the subsidy of the business entity's economy as well as the amount of income tax paid is 3.59, which means that it can be stated that the subsidy affects the business economy in one way or another and subsequently also affects the amount of income tax paid by a business entity to the public budget. 


\section{Conclusions}

The paper assessed the impact of tax policy on the business economy in the agricultural sector. From the performed analysis, it can be stated that:

$\square$ there is a minimum relationship between the size of the business in terms of the size of the assets and the tax payable;

$\square$ there is a relatively slight relationship between the revenue of individual companies and the tax payable;

$\square$ there is an average relationship between the profits of the individual companies and the tax that companies have paid to the public budgets;

$\square$ there is a slight relationship between the subsidy received by individual companies and the tax payable.

Within the framework of the selected agricultural sector, the subsidy policy of the Slovak Republic and the European Union significantly influences the economy of business entities. Since the subsidy policy is not related to production, but to the cultivated area, the subsidies are used to cover the company's costs, thereby distorting the overall economic activity of the company. It can be stated that it would be more profitable for companies within the industry to have as large areas as possible and conduct as few activities as possible, that would have the lowest possible costs, which would increase their profits compared to companies trying to engage in traditional business activities, to grow a certain production, or to keep certain tangible goods and, thus, provide themselves with income. Often, the revenue from the sale of production does not even cover production costs. For this reason, business entities working in the field of agriculture are interested in the amount of the subsidy for the relevant tax period more than the amount of the tax burden expressed in the income tax rate. However, agricultural businesses also have an interest in making the tax system as fair as possible, while keeping tax rates as low as possible.

Based on the conducted quantitative questionnaire survey, it can be stated that:

$\square$ most businesses in the agricultural sector carry out their activities in the form of a legal entity, which indicates that this form is the most advantageous for businesses in terms of liability, corporate governance, and administrative burden.

$\square$ most businesses in the sector employ up to 20 employees, which represents a relatively small number of employees and a departure from previous situations, when the agricultural sector was the main source of job vacancies, especially in rural areas.

$\square$ the reduction in the number of workers in the agricultural sector is mainly due to the inadequate subsidy policy of the state and the European Union, which give preference to large-scale cultivation of selected agricultural crops instead of multi-species production.

$\square$ businesses in the agricultural sector consider the current tax burden to be high, suggesting that this tax burden should be reduced in the future.

$\square$ as an optimal form of tax burden, representatives of companies operating in the agricultural sector prefer a flat tax, which is beneficial from the point of view of long-term and short-term planning.

$\square$ businesses in the agricultural sector do not fully agree with shifting the tax payments from direct to indirect taxes, which is understandable, given that this would mean an increase in the tax burden for them, since most businesses pay taxes on used land, which would increase the amount of taxes paid, and at the same time, if they are engaged in livestock production in real estate, the tax burden will increase again.

$\square$ last but not least, agricultural machinery is relatively expensive, which increases the assets of businesses, and the increase in property taxes will also increase their tax burden, - businesses operating in the agricultural sector agree that businesses with a turnover of up to 100,000 EUR had a lower tax burden.

$\square$ businesses in the agricultural sector prefer that flat-rate expenditure and the non-taxable part of the tax base be preserved, which may also be due to the fact that some of businesses in this sector operate as natural persons.

$\square$ private farmers as well as businesses in the agricultural sector would welcome tax incentives for domestic start-ups in the tax policy, promoting income tax exemptions as the most appropriate tax incentive for the first three years of a business's existence.

$\square$ businesses in the agricultural sector prefer to stimulate employment to tax policy, especially for small and medium-sized enterprises, as well as for self-employed workers.

$\square$ most business entities in the agricultural sector receive subsidies, and the subsidies have a significant impact on the economies of these enterprises and, at the same time, the abolition of those subsidies, which would cause significant economic difficulties for these agricultural enterprises.

$\square$ most businesses in the agricultural sector are not economically strong enough to cope with possible national or global crises on their own, and in the event of such crises these businesses would welcome government assistance, with non-repayable direct financial assistance appearing to be the most preferred form of assistance.

From the above conclusions, it follows that tax policy has an impact on the economy of individual tax entities doing business in the field of agriculture. The aim of these business entities is to make the given tax policy as simple and transparent as possible, and at the same time to be at a comparable level with other neighbouring countries.

\section{References}

BABČ́́K, V. 2015. Daňové právo na Slovensku. Bratislava: Eurounion, 2015. 752 p. ISBN 978-80-5620-091-9.

BELIČKOVÁ, K. 2004. Kontrola a správa daní. Bratislava: Ekonóm, 2004. 192 p. ISBN 80225-1792-5.

BIELIK, P. et al. 2018. Podnikové hospodárstvo. Nitra: SPU, 2018. 363 p. ISBN 978-80-5521903-5.

GURČíK, Ł. 2004. Podnikatel'ská analýza a kontroling. Nitra: SPU, 2004. 158 p. ISBN 808069-449-4.

LÉNÁRTOVÁ, G. 2012. Harmonizácia daní v Európskej únii. Bratislava: Ekonóm, 2012. 114 p. ISBN 978-80-225-3501-4.

LISÝ, J. et al. 2011. Ekonómia. Bratislava: Iura Edition, 2011, 714 p. ISBN 978-80-8087-406-5.

MEDVED̆, J. et al. 2009. Daňová teória a daňový systém. Bratislava: Sprint dva, 2009, 640 p. ISBN 978-80-893-9346-6.

SCHULTZOVÁ, A. 2007. Daňovníctvo, daňová teória a politika. Bratislava: Iura Edition, 2007, 200 p. ISBN 978-80-8078-161-3.

SCHULTZOVÁ, A. et al. 2015. Daňovníctvo - daňová politika a teória I. Bratislava: Wolters Kluwer, 2015, 308 p. ISBN 978-80-7478-867-3.

ŠRENKEL, L. - SMORADA, M. 2017. Analýza finančného zataženia podnikania. Bratislava: Slovak Business Agency, 2017, 135 p. http://www.sbagency.sk/sites/default/files/ file/sba analyza financneho zatazenia-fin.pdf

\section{Contact address}

Miriam Buliková, Slovak University of Agriculture in Nitra, Faculty of Economics and Management, Department of Economics, Tr. Andreja Hlinku 2, 94976 Nitra, Slovakia, tel. +421-903-220082, e-mail: miriam@bulikova.sk 